\title{
STUDY ON PRODUCTIVE EFFICIENCY OF BANKS IN DEVELOPING COUNTRY
}

\author{
1.Bhadrappa Haralayya \\ Post Doctoral Fellowship Research Scholar, \\ Srinivas University, Mangalore, India. \\ bhadrappabhavimani@gmail.com \\ Orcid id-0000-0003-3214-7261 \\ 2.P. S. Aithal, \\ Professor, College of Management and Commerce, \\ Srinivas University, Mangalore, India. \\ psaithal@gmail.com \\ Orcid id-0000-0002-4691-8736
}

\begin{abstract}
The banking sector involves three noteworthy portions: Scheduled Commercial banks, State Cooperative banks, and different banks like NABARD. The booked business banks incorporate every single significant bank and record for over $98 \%$ of the considerable number of assets in the banking sector. The Indian banking industry, which is a noteworthy channel of financing the gainful sector, was to a great extent in the private sector until 1969 when all the real Indian banks in private sector were nationalized. Another arrangement of banks was nationalized in 1980s. A few private sector banks and some remote banks operated, however on a generally little scale. By 1991, most banking assets were in broad daylight sector. Confronting major financial crisis, India began changing its economy in 1991, lessening or taking out controls on numerous sectors, and enabling private sector to take an interest where it was before either denied or limited. Financial sector, including banking sector was likewise changed. The administration additionally chose to streamline the capital market, which
\end{abstract}


was up to this point consumed by one noteworthy stock trade. A noteworthy new stock trade and new administrative body were built up.

Key words-Public Banks, Private Banks and Foreign Banks.

\section{INTRODUCTION}

The productivity is a worried about genuine asset use, yield from a given arrangement of sources of info and estimated as the yield per unit input (or a lot of data sources). This oversimplified methodology is valuable when there is just a single technology, one information and one yield.

Be that as it may, for a firm, simply getting the greatest yield from a given arrangement of information sources isn't sufficient since various innovations, distinctive data sources and diverse arrangements of yields from a similar arrangement of information sources are gotten. In this manner, progressively critical is the adjustment in productivity over some stretch of time, starting with one period then onto the next. Productivity is henceforth, both, static and dynamic in nature: a proportion of, both, the adjustment in technology after some time, and ideal utilization of assets, for the best accessible technology, at a given time. In addition, if the target of the firm is to augment profits, the productivity estimated as proportion of physical units may not be the best measure. Thus, notwithstanding traditional proportion of productivity, an "adapted estimation of productivity" might be a superior performance measure.

Productivity of a firm is in this way gotten from the efficiency of the firm in utilizing ideal technology from a lot of accessible innovations (generation work), ideal arrangement of sources of info given information costs (cost capacity), ideal transformation of a given arrangement of contributions for a given technology into an ideal arrangement of yields (creation work), moves in the generation work (technology changes) and changes in the size of activities (scale and degree). Ideas of efficiency identify with how well a firm utilizes its assets in respect to the current generation potential outcomes outskirts (or, at the end of the day, in respect to current 'best practice') - how a foundation at the same time limits costs and augments income, in view of a current dimension of creation technology. The investigation of a firm efficiency, in this manner, depends on intra-sector examinations, includes both 
innovative and relative evaluating perspectives, and has incomplete marker esteem for dissecting productivity performance.

Table 1.1: Summary performance data for scheduled banks, 2014-15

\begin{tabular}{lcccc}
\hline & $\begin{array}{c}\text { All Schedule Banks } \\
\text { (excluding RRB) }\end{array}$ & $\begin{array}{c}\text { Public Sector } \\
\text { banks }\end{array}$ & $\begin{array}{c}\text { Private Sector } \\
\text { Banks }\end{array}$ & Foreign banks \\
\hline $\begin{array}{l}\text { Number of Commercial } \\
\text { Banks }\end{array}$ & 88 & 28 & 29 & 31 \\
\hline Number of Branches & 54063 & 47794 & 6128 & 141 \\
\hline $\begin{array}{l}\text { Total Deposits, Rs. } \\
\text { Billion }\end{array}$ & 18350 & $14359(78.2)$ & $3126(17.0)$ & $865(4.8)$ \\
\hline $\begin{array}{l}\text { Total loans and } \\
\text { Advances, Rs. billion }\end{array}$ & 11503 & $8547(74.3)$ & $2203(19.2)$ & $753(6.5)$ \\
\hline Total assets, Rs. Billion & 23117 & $17790(77)$ & $3791(16.6)$ & $1536(6.4)$ \\
\hline Net Profit, Rs. Billion & 210.23 & $154.77(73.6)$ & $35.64(17)$ & $19.82(9.4)$ \\
\hline $\begin{array}{l}\text { Average return on } \\
\text { Assets (NP/TA) }\end{array}$ & - & 0.87 & 0.94 & 1.29 \\
\hline NNPA/TA & - & 0.95 & 0.95 & 0.42 \\
\hline $\begin{array}{l}\text { Business per employee, } \\
\text { Rs. M }\end{array}$ & - & 30.6 & 57.7 & 94 \\
\hline
\end{tabular}

Table1.2. Summary performance data for scheduled banks, 2011-12

\begin{tabular}{lcccc}
\hline & $\begin{array}{c}\text { All Schedule Banks } \\
\text { (excluding RRB) }\end{array}$ & $\begin{array}{c}\text { Public Sector } \\
\text { banks }\end{array}$ & $\begin{array}{c}\text { Private Sector } \\
\text { Banks }\end{array}$ & Foreign banks \\
\hline $\begin{array}{l}\text { Number of Commercial } \\
\text { Banks }\end{array}$ & 97 & 27 & 30 & 40 \\
\hline Number of Branches & 51889 & 46384 & 5311 & 194 \\
\hline $\begin{array}{l}\text { Total Deposits, Rs. } \\
\text { Billion }\end{array}$ & 11997 & $9657(80.5)$ & $1694(14.1)$ & $645(5.4)$ \\
\hline $\begin{array}{l}\text { Total loans and } \\
\text { Advances, Rs. Billion }\end{array}$ & 6447 & $4807(74.6)$ & $1184(18.3)$ & $456(7.1)$ \\
\hline Total assets, Rs. Billion & 16040 & $12030(75)$ & $2780(17.3)$ & $1230(7.7)$ \\
\hline Net Profit, Rs. Billion & 116 & $83.3(75.7)$ & $17.8(10.7)$ & $14.9(13.6)$ \\
\hline $\begin{array}{l}\text { Average return on } \\
\text { Assets NP/TA) }\end{array}$ & -- & 0.72 & 0.65 & 1.32 \\
\hline NNPA/TA & -- & 2.42 & 2.49 & 0.79 \\
\hline $\begin{array}{l}\text { Business per employee, } \\
\text { Rs. M }\end{array}$ & - & 19.2 & 39.7 & 81.5 \\
\hline
\end{tabular}

Table1.3. Summary performance data for scheduled banks, 2009 


\begin{tabular}{|c|c|c|c|c|}
\hline & $\begin{array}{l}\text { All Schedule Banks } \\
\text { (excluding RRB) }\end{array}$ & $\begin{array}{l}\text { Public Sector } \\
\text { banks }\end{array}$ & $\begin{array}{c}\text { Private Sector } \\
\text { Banks }\end{array}$ & $\begin{array}{l}\text { Foreign } \\
\text { banks }\end{array}$ \\
\hline $\begin{array}{l}\text { Number of Commercial } \\
\text { Banks }\end{array}$ & 79 & 32 & 23 & 24 \\
\hline Number of Branches & 47021 & 42932 & 3939 & 150 \\
\hline $\begin{array}{l}\text { Total Deposits, Rs. } \\
\text { Billion }\end{array}$ & 1957 & $1756(89.7)$ & $87.3(4.5)$ & $113.7(5.8)$ \\
\hline $\begin{array}{l}\text { Total loans and } \\
\text { Advances, Rs. Billion }\end{array}$ & 1204 & $1061.1(88.1)$ & $49.7(4.1)$ & $93.6(7.8)$ \\
\hline Total assets, Rs. Billion & 3120 & $\mathrm{NA}$ & $\mathrm{NA}$ & $\mathrm{NA}$ \\
\hline Net Profit, Rs. Billion & 12.16 & $\mathrm{NA}$ & NA & NA \\
\hline $\begin{array}{l}\text { Average return on } \\
\text { Assets (NP/TA) }\end{array}$ & 0.39 & 0.32 & 0.57 & 1.57 \\
\hline NNPA/TA & $\mathrm{NA}$ & $\mathrm{NA}$ & $\mathrm{NA}$ & $\mathrm{NA}$ \\
\hline $\begin{array}{l}\text { Business per employee, } \\
\text { Rs. M }\end{array}$ & NA & $\mathrm{NA}$ & NA & $\mathrm{NA}$ \\
\hline
\end{tabular}

\section{DEFINITION AND MEASUREMENT OF INPUTS AND OUTPUTS FOR BANKING INDUSTRY}

In contrast to the assembling industry, inputs and outputs are not very much characterized in an administration industry. Administration is delivered utilizing certain inputs and technology, and has a related creation work. In this manner, one methodology, in banking industry, is Production approach for estimating inputs and outputs. Thoughtfully it depends on genuine asset model. In this methodology banks are accepted to utilize physical inputs to deliver outputs like deposits and credits. In this methodology, inputs are number of representatives, normal number of workers per branch, capital utilized, number of branches, number of deposit accounts, and so forth. The outputs are number of loanee accounts, number of exchanges, number of deposit accounts, and so forth. (A few scientists take deposit accounts as inputs, others accept them as outputs.)

Numerous analysts adopt an alternate strategy, an Intermediation Approach, likewise called as an Asset Approach. It depends on action model. An average bank obtains cash in type of a deposit and loans it in type of a credit. This is the essential capacity of a bank. Therefore banks go about as delegates between proprietors of assets and clients of assets. The commitment of physical inputs to value expansion is insignificant. Subsequently, in this methodology, dissimilar to creation approach, inputs and outputs are considered in financial values. Commonly, inputs are money related value of inputs, 
for example, work, capital and assets. In this way intrigue cost, work cost, other working costs are viewed as inputs. The outputs are the financial value of procuring assets, for example, value of advances, value of deposits, ventures, net pay, and so forth.

The two methodologies have their constraints. Serious issue is the manner by which to total yield (input) in a solitary list. Likewise, whatever be the strategy, cross examination with different banks isn't simple. In either approach, there is no unanimity on what precisely ought to be the inputs and the outputs. In intermediation approach, the selection of inputs and outputs is subjective. Regardless of whether deposits are inputs or outputs isn't clear and diverse creators have utilized deposits as either inputs or outputs. Some consider work cost as a different input; others take working cost and intrigue cost alone as inputs. On the yield side charge based salary might be considered as independent yield. The intermediation approach disregards different administrations given by the banks, e.g., withdrawal office to deposit holders. Banks additionally have different assets separated by liquidity and hazard. So also, underway methodology, number of bank branches could possibly be taken as input. In the creation approach, there is no clearness on the best way to represent, say, remote deposits and government securities.

\section{PRODUCTIVE EFFICIENCY OF BANKS}

The monetary theory of the firm expect that production happens in a domain in which supervisors endeavor to boost benefits by working in the most proficient way conceivable. The focused model proposes that organizations which neglect to do as such will be driven from the market by progressively proficient ones. Be that as it may, when characteristic section obstructions or direction debilitate focused powers, wasteful firms may keep on flourishing. That is, genuine firm conduct may differ from that inferred by the focused model as directors endeavor to amplify their very own prosperity rather than benefits, or find that they are not required to work very proficiently to stay in business. Varieties from productiveefficiency can be separated into information and yield incited wasteful aspects. By info wastefulness we imply that, for a given dimension of yield, the firm isn't ideally utilizing the elements of production. In general information wastefulness coming about because of the imperfect 
utilization of sources of info can be deteriorated into allocative and unadulterated specialized wastefulness. Allocative wastefulness happens when inputs are consolidated in problematic extents. Direction is regularly given as a noteworthy explanation behind this event. Unadulterated specialized wastefulness happens when a greater amount of each info is utilized than ought to be required to deliver a given dimension of yield. This event is increasingly hard to clarify, yet is commonly credited to feeble aggressive powers which enable administration to "escape" with loosened profitability. Consolidating these two ideas of wastefulness we get the general wastefulness coming about because of the inappropriate utilization of data sources.' The refinement between the two sorts of wastefulness is critical in light of the fact that they might be brought about by very surprising powers.

\section{OBJECTIVES OF THE STUDY}

Therefore, in the light of the above dialog, the explicit targets of the study are:

1) To study the budgetary execution and look at the development of Indian business banks in India in the pre-and post-change period.

2) To break down the efficiency gains crosswise over various gatherings of banks and assess the cost, a locative, specialized, unadulterated specialized and scale efficiencies.

3) To break down contrasts in profitability crosswise over bank types in the pre-and post-change periods.

4) To look at the real markers that influences the efficiency.

\section{RESEARCH METHODOLOGY}

This part presents and legitimizes kind of systems received in assessing the dimension of effectiveness and TFP of banks in India. The present part of the examination is isolated into three segments. The area I talks about problem, need and targets of the investigation. The segment II talks about the organization of the information and determination of data sources and yields to evaluate the outcomes as far as proficiency and efficiency markers. At last, the 
segment III tosses light on models embraced to quantify effectiveness and TFP level along with determinants.

Figure 5.1: Analysis of Various Approaches (in per cent)

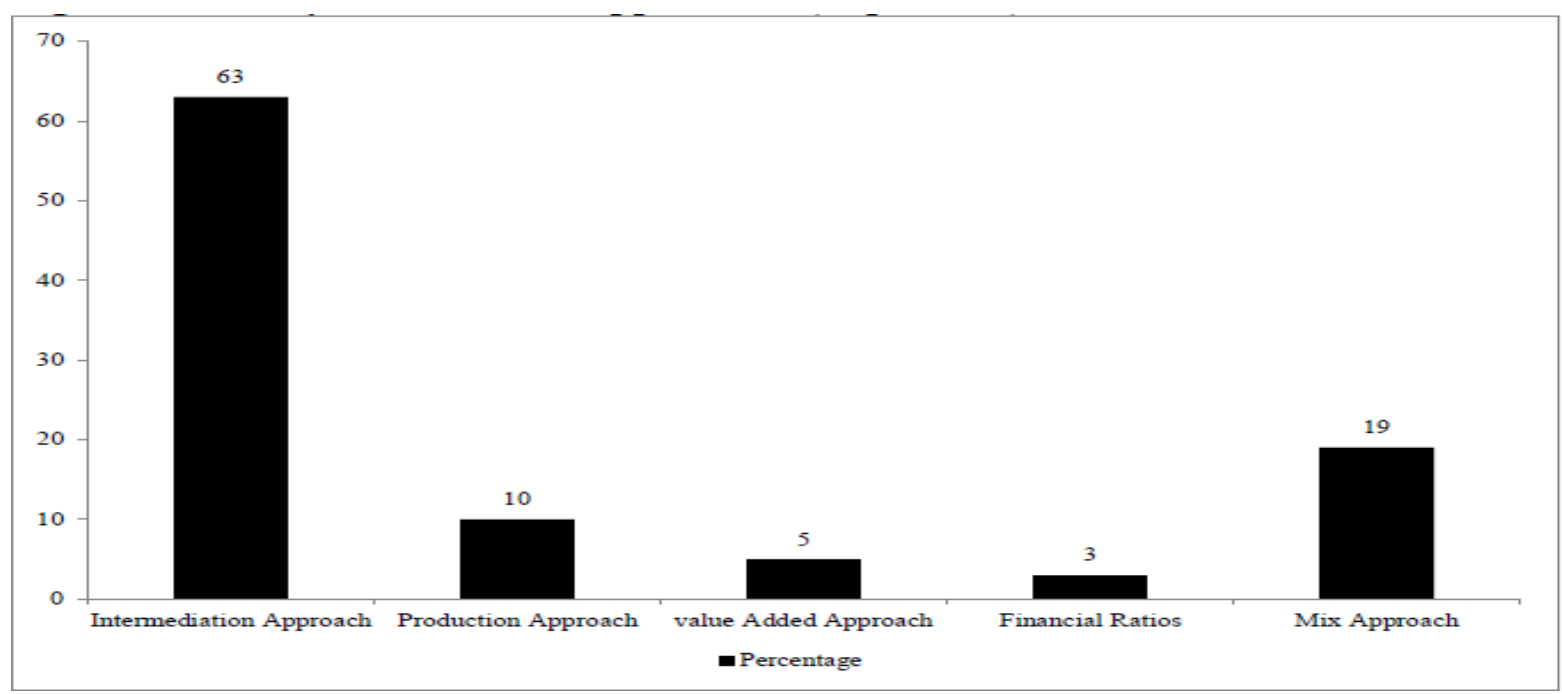

Source: Anouze, 2010, p.47.

Table 5.1: Quartile Representation of Scheduled Commercial Banks in India 1994-95

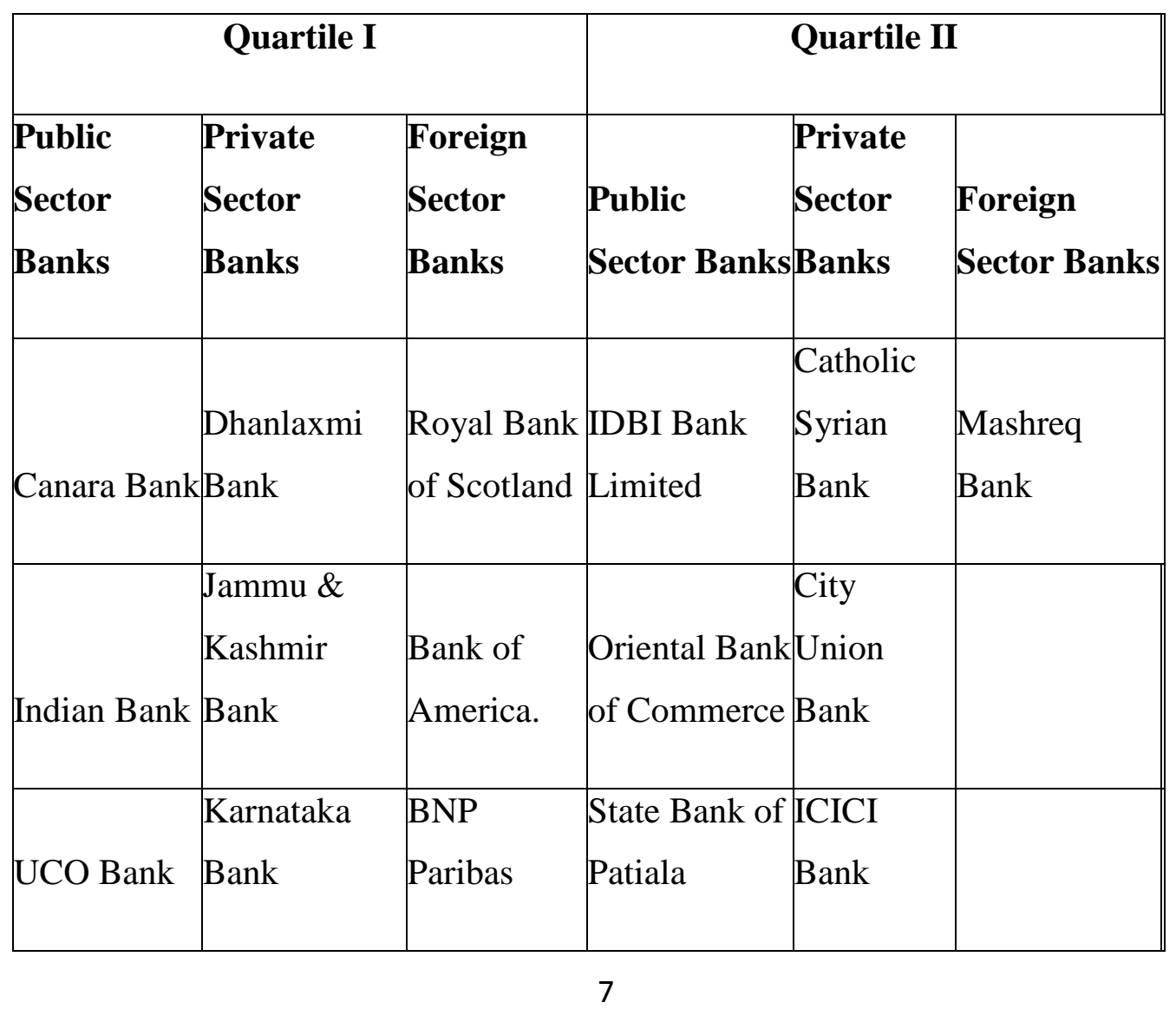




\begin{tabular}{|c|c|c|c|c|c|}
\hline $\begin{array}{l}\text { Union Bank } \\
\text { of India }\end{array}$ & $\begin{array}{l}\text { Lakshmi } \\
\text { Vilas Bank }\end{array}$ & HSBC & Vijaya Bank & & \\
\hline & $\begin{array}{l}\text { South Indian } \\
\text { Bank }\end{array}$ & $\begin{array}{l}\text { Societe } \\
\text { Generale }\end{array}$ & & & \\
\hline & $\begin{array}{l}\text { HSBC Bank } \\
\text { Oman }\end{array}$ & & & & \\
\hline & Quartile III & & & Quartile IV & \\
\hline $\begin{array}{l}\text { Public } \\
\text { Sector } \\
\text { Banks }\end{array}$ & $\begin{array}{l}\text { Private } \\
\text { Sector } \\
\text { Banks }\end{array}$ & $\begin{array}{c}\text { Foreign } \\
\text { Sector } \\
\text { Banks }\end{array}$ & $\begin{array}{c}\text { Public } \\
\text { Sector Banks }\end{array}$ & $\begin{array}{c}\text { Private } \\
\text { Sector } \\
\text { Banks }\end{array}$ & $\begin{array}{c}\text { Foreign } \\
\text { Sector Banks }\end{array}$ \\
\hline $\begin{array}{l}\text { Bank of } \\
\text { Baroda }\end{array}$ & Federal bank & \begin{tabular}{|l} 
Bank of \\
Bahrain \& \\
Kuwait
\end{tabular} & $\begin{array}{l}\text { Allahabad } \\
\text { bank }\end{array}$ & Axis Bank & $\begin{array}{l}\text { Abu Dhabi } \\
\text { Commercial } \\
\text { Bank }\end{array}$ \\
\hline $\begin{array}{l}\text { Bank of } \\
\text { India }\end{array}$ & HDFC Bank & $\begin{array}{l}\text { Bank of } \\
\text { Tokyo- } \\
\text { Mitsubishi }\end{array}$ & Andhra Bank & $\begin{array}{l}\text { Indusind } \\
\text { Bank }\end{array}$ & $\begin{array}{l}\text { Bank of Nova } \\
\text { Scotia }\end{array}$ \\
\hline Dena Bank & $\begin{array}{l}\text { ING Vysya } \\
\text { Bank }\end{array}$ & Citi Bank & $\begin{array}{l}\text { Bank of } \\
\text { Maharashtra }\end{array}$ & & $\begin{array}{l}\text { Barclays } \\
\text { Bank }\end{array}$ \\
\hline $\begin{array}{l}\text { Indian } \\
\text { Overseas } \\
\text { Bank }\end{array}$ & $\begin{array}{l}\text { Karur Vysya } \\
\text { Bank }\end{array}$ & DBS Bank & $\begin{array}{l}\text { Central Bank } \\
\text { of India }\end{array}$ & & $\begin{array}{l}\text { Deutsche } \\
\text { Bank }\end{array}$ \\
\hline $\begin{array}{l}\text { Punjab and } \\
\text { Sind Bank }\end{array}$ & Nainital Bank & $\begin{array}{l}\text { JP Morgan } \\
\text { Chase Bank }\end{array}$ & $\begin{array}{l}\text { Corporation } \\
\text { Bank }\end{array}$ & & Sonali Bank \\
\hline $\begin{array}{l}\text { State Bank } \\
\text { of India }\end{array}$ & $\begin{array}{l}\text { Ratnakar } \\
\text { Bank Limited }\end{array}$ & $\begin{array}{l}\text { Standard } \\
\text { Chartered } \\
\text { Bank }\end{array}$ & $\begin{array}{l}\text { Punjab } \\
\text { National } \\
\text { Bank }\end{array}$ & & \\
\hline
\end{tabular}




\begin{tabular}{|c|c|c|c|c|c|}
\hline State Bank & Tamilnad & State Bank & State Bank of & & \\
\hline of & Mercantile & of & Bikaner \& & & \\
\hline Hyderabad & Bank & Mauritius & Jaipur & & \\
\hline $\begin{array}{l}\text { State Bank } \\
\text { of Mysore }\end{array}$ & & & $\begin{array}{l}\text { State Bank of } \\
\text { Travancore }\end{array}$ & & \\
\hline $\begin{array}{l}\text { Syndicate } \\
\text { Bank }\end{array}$ & & & $\begin{array}{l}\text { United Bank } \\
\text { of India }\end{array}$ & & \\
\hline \multicolumn{6}{|c|}{ 2013-14 } \\
\hline \multicolumn{3}{|c|}{ Quartile I } & \multicolumn{3}{|c|}{ Quartile II } \\
\hline \begin{tabular}{|l} 
Public \\
Sector \\
Banks
\end{tabular} & $\begin{array}{c}\text { Private } \\
\text { Sector } \\
\text { Banks }\end{array}$ & $\begin{array}{c}\text { Foreign } \\
\text { Sector } \\
\text { Banks }\end{array}$ & $\begin{array}{c}\text { Public } \\
\text { Sector Banks }\end{array}$ & $\begin{array}{l}\text { Private } \\
\text { Sector } \\
\text { Banks }\end{array}$ & $\begin{array}{c}\text { Foreign } \\
\text { Sector Banks }\end{array}$ \\
\hline $\begin{array}{l}\text { Union Bank } \\
\text { of India }\end{array}$ & $\begin{array}{l}\text { Jammu \& } \\
\text { Kashmir } \\
\text { Bank }\end{array}$ & $\begin{array}{l}\text { Societe } \\
\text { Generale }\end{array}$ & Indian Bank & $\begin{array}{l}\text { Dhanlaxm } \\
\text { Bank }\end{array}$ & $\begin{array}{l}\text { Royal Bank } \\
\text { of Scotland }\end{array}$ \\
\hline $\begin{array}{l}\text { Corporation } \\
\text { Bank }\end{array}$ & $\begin{array}{l}\text { South Indian } \\
\text { Bank }\end{array}$ & & & $\begin{array}{l}\text { Karnataka } \\
\text { Bank }\end{array}$ & BNP Paribas \\
\hline & Quartile III & & & $\begin{array}{l}\text { Quartile } \\
\text { IV }\end{array}$ & \\
\hline $\begin{array}{l}\text { Public } \\
\text { Sector } \\
\text { Banks }\end{array}$ & $\begin{array}{l}\text { Private } \\
\text { Sector Banks }\end{array}$ & $\begin{array}{l}\text { Foreign } \\
\text { Sector } \\
\text { Banks }\end{array}$ & $\begin{array}{l}\text { Public Sector } \\
\text { Banks }\end{array}$ & $\begin{array}{l}\text { Private } \\
\text { Sector } \\
\text { Banks }\end{array}$ & $\begin{array}{l}\text { Foreign } \\
\text { Sector Banks }\end{array}$ \\
\hline $\begin{array}{l}\text { Bank of } \\
\text { Baroda }\end{array}$ & $\begin{array}{l}\text { Catholic } \\
\text { Syrian Bank }\end{array}$ & $\begin{array}{l}\text { Abu Dhabi } \\
\text { Commercial } \\
\text { Bank }\end{array}$ & $\begin{array}{l}\text { 1/Allahabad } \\
\text { bank }\end{array}$ & Axis Bank & $\begin{array}{l}\text { Bank of Nova } \\
\text { Scotia }\end{array}$ \\
\hline
\end{tabular}




\begin{tabular}{|c|c|c|c|c|c|}
\hline $\begin{array}{l}\text { Bank of } \\
\text { India }\end{array}$ & $\begin{array}{l}\text { City Union } \\
\text { Bank }\end{array}$ & $\begin{array}{l}\text { Bank of } \\
\text { America. }\end{array}$ & Andhra Bank & $\begin{array}{l}\text { Indusind } \\
\text { Bank }\end{array}$ & $\begin{array}{l}\text { Barclays } \\
\text { Bank }\end{array}$ \\
\hline Canara Bank & kFederal bank & \begin{tabular}{|l|} 
Bank of \\
Bahrain \& \\
Kuwait
\end{tabular} & $\begin{array}{l}\text { Bank of } \\
\text { Maharashtra }\end{array}$ & & $\begin{array}{l}\text { Deutsche } \\
\text { Bank }\end{array}$ \\
\hline Dena Bank & HDFC Bank & $\begin{array}{l}\text { Bank of } \\
\text { Tokyo- } \\
\text { Mitsubishi }\end{array}$ & $\begin{array}{l}\text { Central Bank } \\
\text { of India }\end{array}$ & & Sonali Bank \\
\hline $\begin{array}{l}\text { IDBI Bank } \\
\text { Limited }\end{array}$ & ICICI Bank & Citi Bank & $\begin{array}{l}\text { State Bank of } \\
\text { Bikaner \& } \\
\text { Jaipur }\end{array}$ & & \\
\hline $\begin{array}{l}\text { Indian } \\
\text { Overseas } \\
\text { Bank }\end{array}$ & $\begin{array}{l}\text { ING Vysya } \\
\text { Bank }\end{array}$ & DBS Bank & $\begin{array}{l}\text { United Bank } \\
\text { of India }\end{array}$ & & \\
\hline $\begin{array}{l}\text { Oriental } \\
\text { Bank of } \\
\text { Commerce }\end{array}$ & $\begin{array}{l}\text { Karur Vysya } \\
\text { Bank }\end{array}$ & HSBC & & & \\
\hline $\begin{array}{l}\text { Punjab and } \\
\text { Sind Bank }\end{array}$ & $\begin{array}{l}\text { Lakshmi } \\
\text { Vilas Bank }\end{array}$ & $\begin{array}{l}\text { JP Morgan } \\
\text { Chase Bank }\end{array}$ & & & \\
\hline $\begin{array}{l}\text { Punjab } \\
\text { National } \\
\text { Bank }\end{array}$ & Nainital Bank & $\begin{array}{l}\text { Mashreq } \\
\text { Bank }\end{array}$ & & & \\
\hline $\begin{array}{l}\text { State Bank } \\
\text { of India }\end{array}$ & $\begin{array}{l}\text { Ratnakar } \\
\text { Bank Limited }\end{array}$ & $\begin{array}{l}\text { HSBC } \\
\text { Bank Oman }\end{array}$ & & & \\
\hline $\begin{array}{l}\text { State Bank } \\
\text { of }\end{array}$ & $\begin{array}{l}\text { Tamilnad } \\
\text { Mercantile }\end{array}$ & $\begin{array}{l}\text { Standard } \\
\text { Chartered }\end{array}$ & & & \\
\hline
\end{tabular}




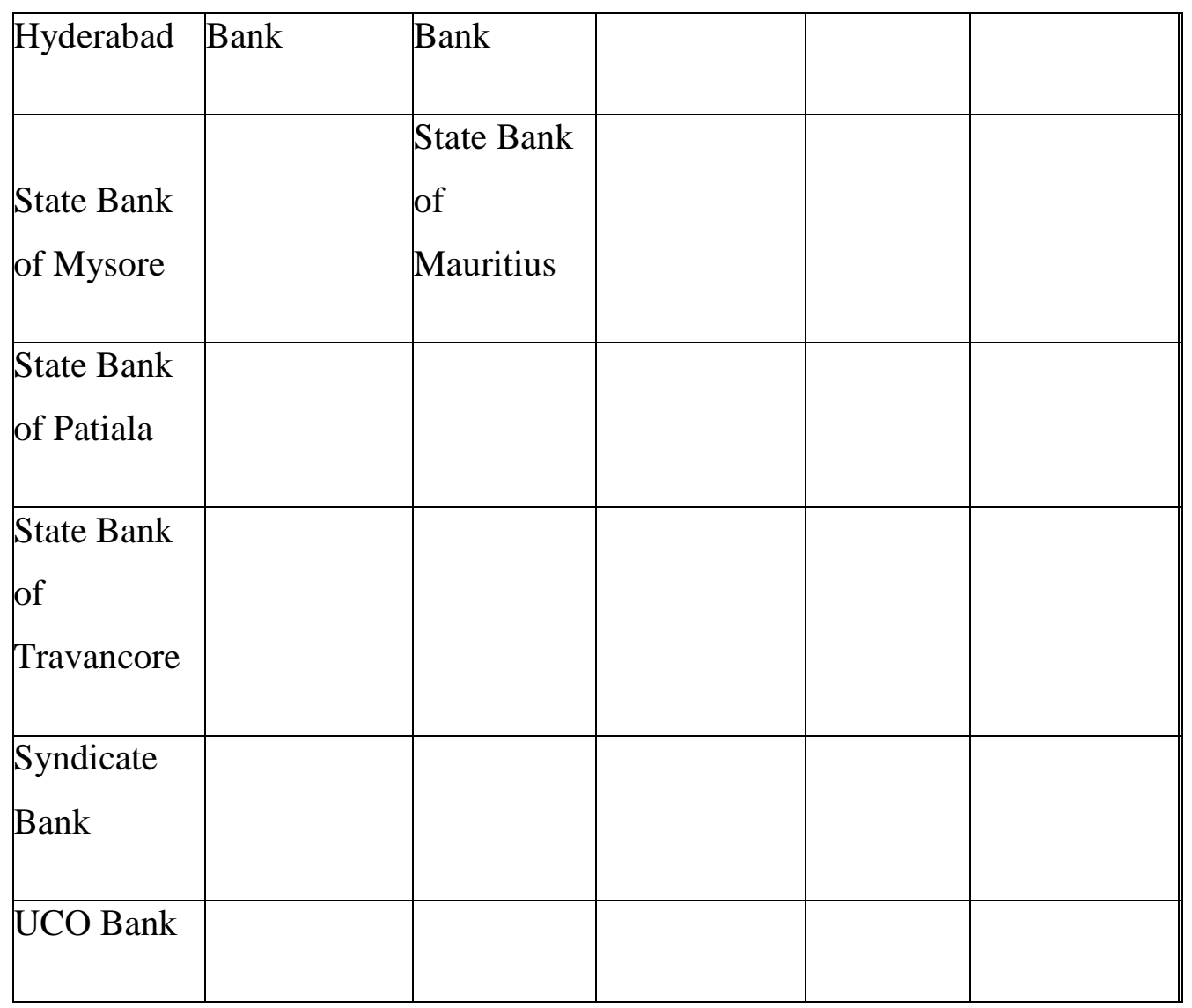

Figure 5.2: Bank-Wise Comparative Analysis of Total Factor Productivity Scores for Public Sector Banks in India.

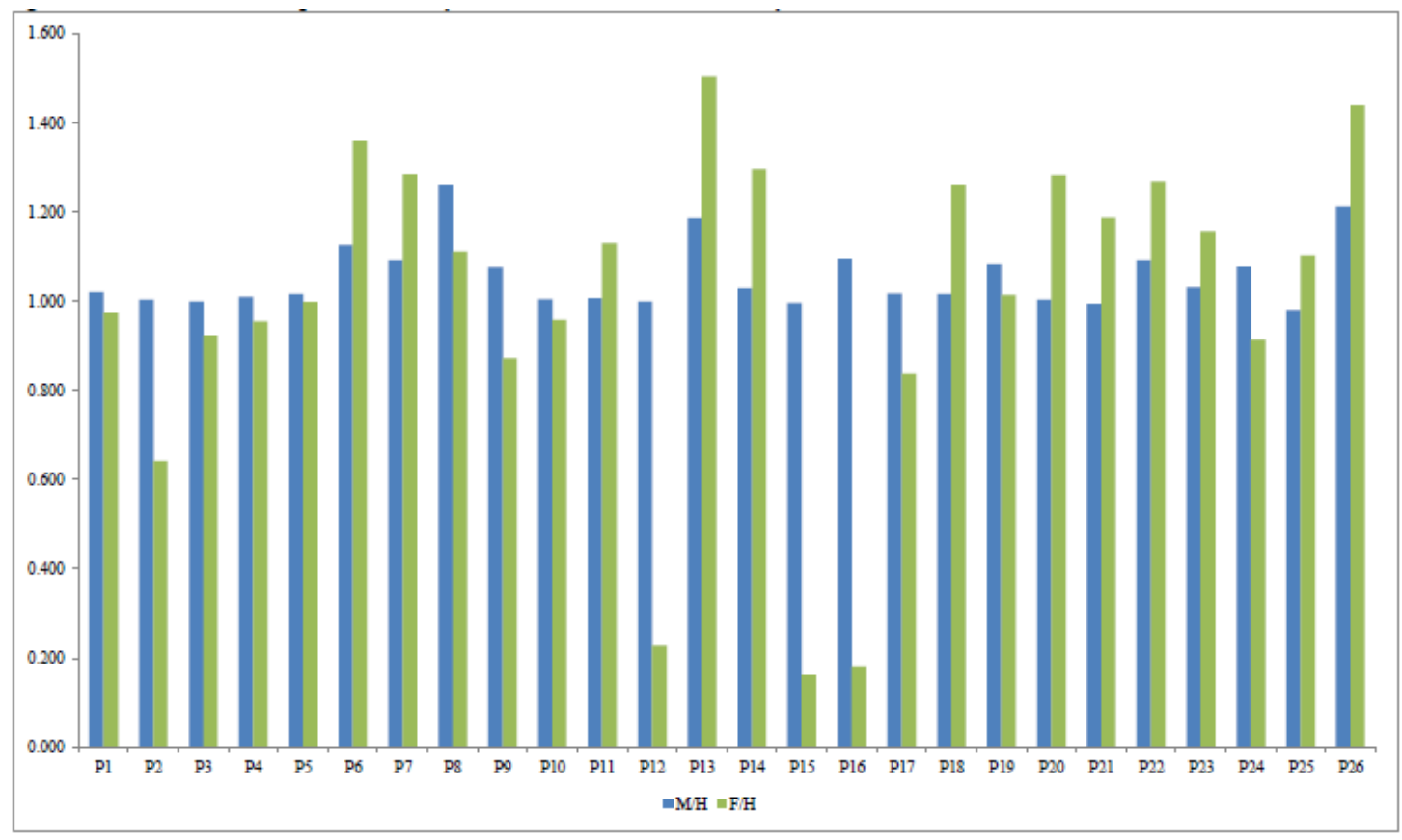


Figure 5.3: Bank-Wise Comparative Analysis of Total Factor Productivity Scores for Private Sector Banks in India.

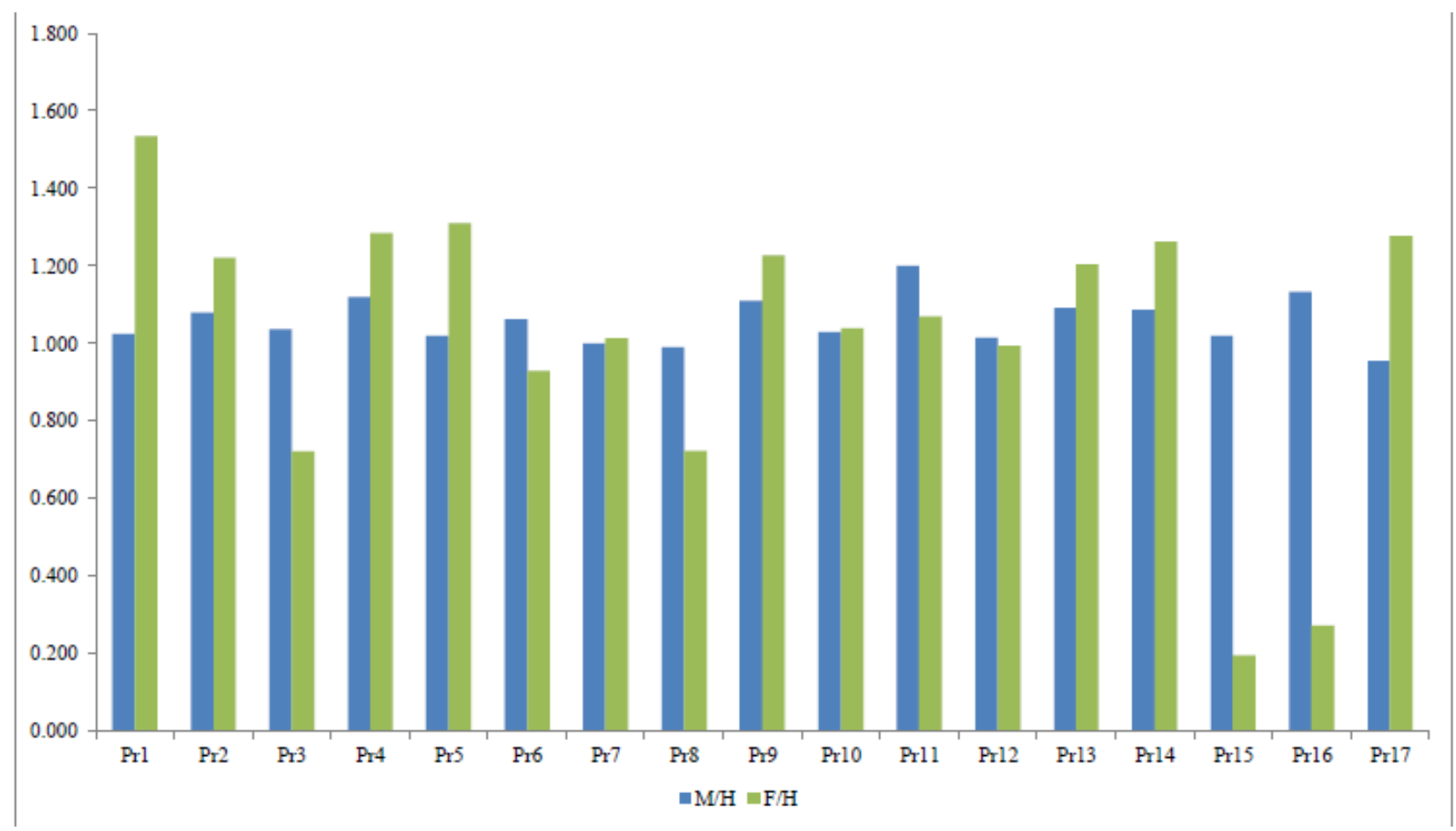

Figure 5.4: Bank-Wise Comparative Analysis of Total Factor Productivity Scores for Foreign Sector Banks in India.

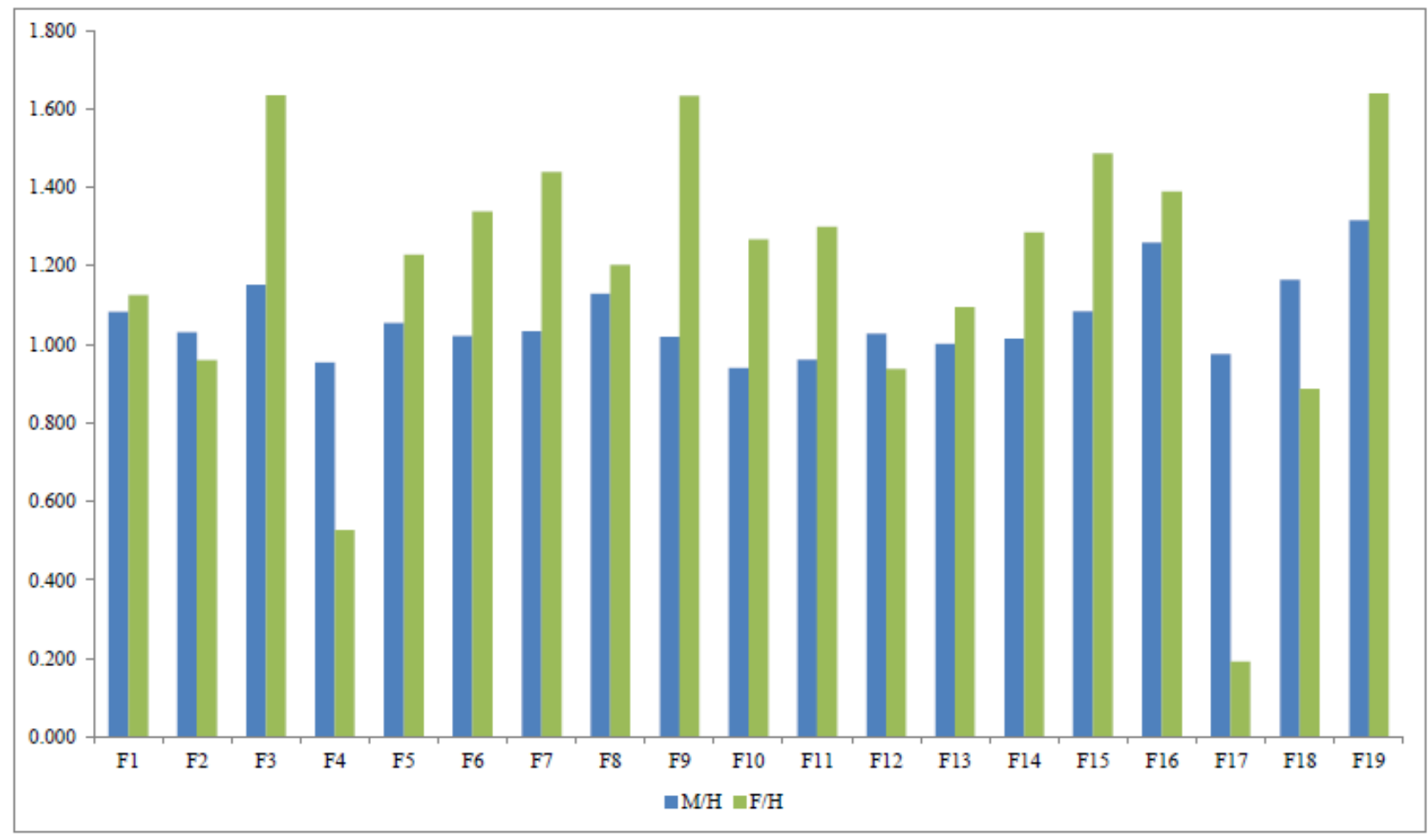




\section{CONCLUSION}

Banks should concentrate more on quality portfolios and preferred middle person benefits fairly over on ads as it were. By quality, the investigation implies that in spite of the fact that there have been number of records opened after the budgetary consideration process, however the quantity of exchanges stays tiny. Therefore, banks are not ready to catch the potential accessible in the market which might be because of poor administration and less assortment in money related items and administrations. Offering mono-item benefits with various names ought to be recognized by the banks in India and there is have to offer wide assortment of items through imaginative innovation. Such activities would lead towards expanding the quantity of exchange and decrease in the promotion uses. Banks need to enhance their tasks and give advances to various items to the diverse sections of society with changes to their greatest advantage rates at ordinary interims. There should have a legitimate control on the different kinds of working costs in the bank offices as it has all the earmarks of being the main factor for financial inefficiency. To make the administration working sound and gainful, there is have to investigate the costs identified with lease, expenses and lightning, printing and stationary, postage, fixes and systems for upkeeps, and so on. It is additionally recommended that

\section{REFRENCES}

1. Aggarwal , M. 2007. Productivity of Commercial Banks in India- Trends and Analysis . Gyan Publishing House, New Delhi.

2. Amandeep 1993. Profits and Profitability of Commercial Banks. Deep and Deep Publications, New Delh.

3. American Bankers Association 1983. Productivity improvement for Banking Office- A Comprehensive Guide Book. American Banker's Association, Washington.

4. Burns, A.C. and Bush, R.F. 2007. Marketing Research. Pearson Education, New Delhi.

5. Garg, P., Jham, V. 2006 Indian Banks and ATM-An Emprical study of Consumer Perceptions, Strategies of Winning Organizations, Edited by Upinder Dhar, Santosh Dhar and Vinit Singh Chauhan. Excell Books, New Delhi. pp. 516-23. 
6. Gupta, S.P. 2007. Statistical Methods. S. Chand and Sons, New Delhi.

7. Haralayya, Dr. Bhadrappa, The Productive Efficiency of Banks in Developing Country With Special Reference to Banks \& Financial Institution (april 30, 2019). Available

SSRN: https://ssrn.com/abstract=3844432 or http://dx.doi.org/10.2139/ssrn.38 44432

8. Haralayya, Dr. Bhadrappa, Study on Performance of Foreign Banks in India (APRIL 2016). Available at SSRN: https://ssrn.com/abstract=3844403 or http://dx.doi.org/10.2139/ssrn.38 44403

9. Haralayya, Dr. Bhadrappa, E-Finance and the Financial Services Industry (MARCH 28, 2014). Available at SSRN: https://ssrn.com/abstract=3844405 or http://dx.doi.org/10.2139/ssrn.38 44405

10. Haralayya, Dr. Bhadrappa and Saini, Shrawan Kumar, An Overview on Productive Efficiency of Banks \& Financial Institution (2018). International Journal of Research, Volume 05 Issue 12, April 2018, Available at SSRN: https://ssrn.com/abstract $=3837503$

11. Haralayya, Dr. Bhadrappa, Review on the Productive Efficiency of Banks in Developing Country (2018). Journal for Studies in Management and Planning, Volume 04 Issue 05, April 2018, Available at SSRN: https://ssrn.com/abstract=3837496

12. Heggade, O.D. 2000. Banker - Customer Relationship in India. Mohit Publications, Ph.D. thesis Published, New Delhi.

13. Lee, Schniederjans 1994. Operations Management. Houghton Mifflin Co., Toronto.

14. Malik, A.K. 1995. Managing Computerization. Radha Publications, New Delhi.

15. Mohan , R. 2009. Monetary Policy in a Globalized Economy - A Practitioner's View. Oxford University Press, New Delh.

16. Basha, Jeelan and Haralayya, Dr. Bhadrappa, Performance Analysis of Financial Ratios - Indian Public Non-Life Insurance Sector (April 30, 2021). Available at SSRN: https://ssrn.com/abstract=3837465. 